Historic, archived document

Do not assume content reflects current scientific knowledge, policies, or practices. 



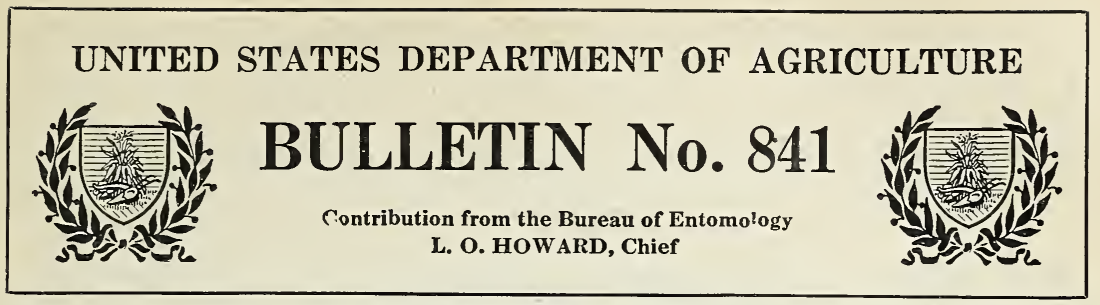

Washington, D. C.

PROFESSIONAL PAPER

May 7, 1920

\section{THE WESTERN GRASS-STEM SAWFLY}

By C. N. Arnsuie, ${ }^{1}$ Entomological Assistant, Cereal and Forage Insect Investigations

\section{CONTENTS}

\begin{tabular}{|c|c|c|c|}
\hline & Page & & Page \\
\hline (n........ & 1 & The adult... & 17 \\
\hline History $\ldots . . . . . . .$. & 2 & Oviposition... & 9 \\
\hline Food plants.. & 8 & Key to North American species of Cephus... & 22 \\
\hline The egg..... & 9 & 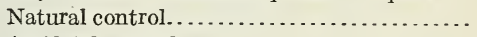 & 20 \\
\hline Development of the egg..... & 10 & Artificial control.................... & 4 \\
\hline rva............. & 11 & Cephus pygmaeus (L.)......... & 66 \\
\hline e pupa................... & 16 & Description......................... & \\
\hline
\end{tabular}

\section{INTRODUCTION}

The western grass-stem sawfly (Cephus cinctus Norton) (fig. 1) is in many ways one of the most interesting and important insects that has attracted the especial attention of economic entomologists in recent years. It is a species native to the United States and has been gradually coming into prominence since the beginning of the present century by reason of the change which the feeding habits of the larvæ have been undergoing subsequent to its discovery. Originally a grass feeder, it is becoming a serious menace to the grain growers of the Northwestern States because of its acquired appetite for small grains, within the stems of which it now subsists.

Such changes of diet are probably occurring everywhere with greater frequency than formerly was deemed possible, especially among the phytophagous insects of the Middle West. When given a

1 The writer wishes to express his appreciation of the assistance afforded by Messrs. J. C. Crawford, A. B. Gahan, and S. A. Rohwer, of the Bureau of Entomology, in the preparation of this paper, the two former in determining parasitic material reared during the progress of the studies of the sawfly, the latter in making a critical examination of a large series of sawfly individuals reared or collected from various parts of North America, and for furnishing detailed descriptions of Cephus cinctus besides a key to the North American species of the genus Cephus. Helpful criticisms from these men have added to the value and accuracy of the paper.

The writer desires also to mention the valuable assistance and cordial cooperation of Mr. Norman Criddle, entomological field officer for Manitoba, Canada; of Mr. A. P. Henderson, of Bottineau, N. Dak., and of the several county agents in the infested areas, who have aided in various ways in the accumulation of information and material. 
chance to feed upon the rarious cultivated plants grown in bulk by the farmer or gardener, many of these insects gradually desert their native host plants and to a greater or less degree change their habits, including in their fare the more succulent and easily found food.

\section{HISTORY}

The existence of the western grass-stem sawfly was first made known in 1890 when Mr. Albert Koebele reared adults from larræ that were mining in the stems of natire grasses growing in the ricinity of Alameda, Calif. ${ }^{1}$ During the next year, 1S91, the species was described under the name of Cephus occidentatis by Messrs. Riley and Marlatt, from a series of individuals reared by Mr. Koebele and also

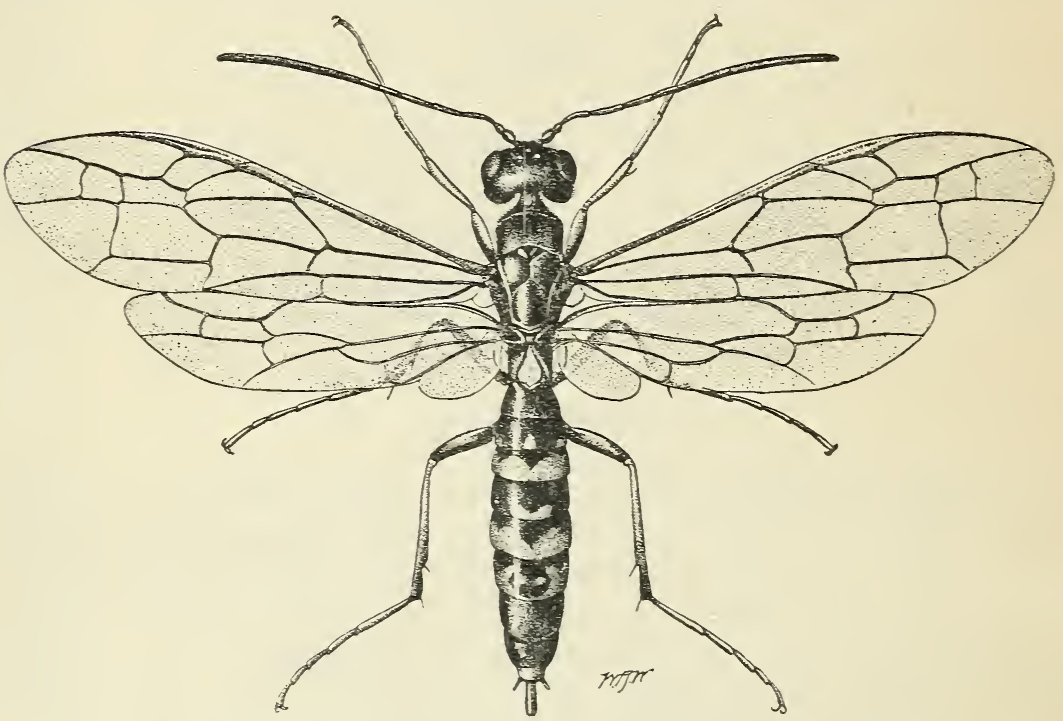

FIG. 1.-Western grass-stem sawfly (Cephus cinclus): Idult female. Much enlarged.

from cotypes that had in the meantime been collected in Nerada and Montana. ${ }^{2}$ In connection with this description the prophetic suggestion was made that: "The economic importance of this species arises from the fact that it may be expected at any time to abandon its natural food-plant in faror of the small grains, on which it can doubtless successfully derelop."

Nothing more was heard of this sawfly until 1895, when the late Dr. James Fletcher, Entomologist to the Dominion of Canada, swept adults at Indian Head, Northwest Territories, on July 5. He beliered it to belong to the European species, Cephus pygmaeus L., and under

${ }^{1}$ Koebele, A. Notes. In U. S. Dept. Agr. Dir. Ent. Insect Life, r. 3, p. 71, 1890.

${ }^{2}$ Riley, C. V., and Marlatt, C. L. Wheat and Grass Saw-Flies. In U. S. Dept. Agr. Div. Ent. Insect Life, v. 4, p. 168-179, 1891. (See p. 177-178.) 
this name it was mentioned in his report for $1896^{1}$ with the further statement that wheat straws containing Cephus larvæ had been sent in by Mr. John Wenman of Souris, Manitoba, who stated that the injury done by them was very slight. Nevertheless the prophecy of five years before had been fulfilled, since these grass feeders actually had attacked small grain.

In 1902 Dr. Fletcher reported, in a private letter, that he had found the larvæ numerous in grasses in the Northwest. In 1905 and 1906 Mr. G.I. Reeves, an agent of the Bureau of Entomology, noted the work of the larvæ in rarious grasses, chiefly Agropyron sp., in Wyoming and the Dakotas, and in 1906 the same observer found the larvæ attacking wheat sparingly near Kulm, N. Dak.

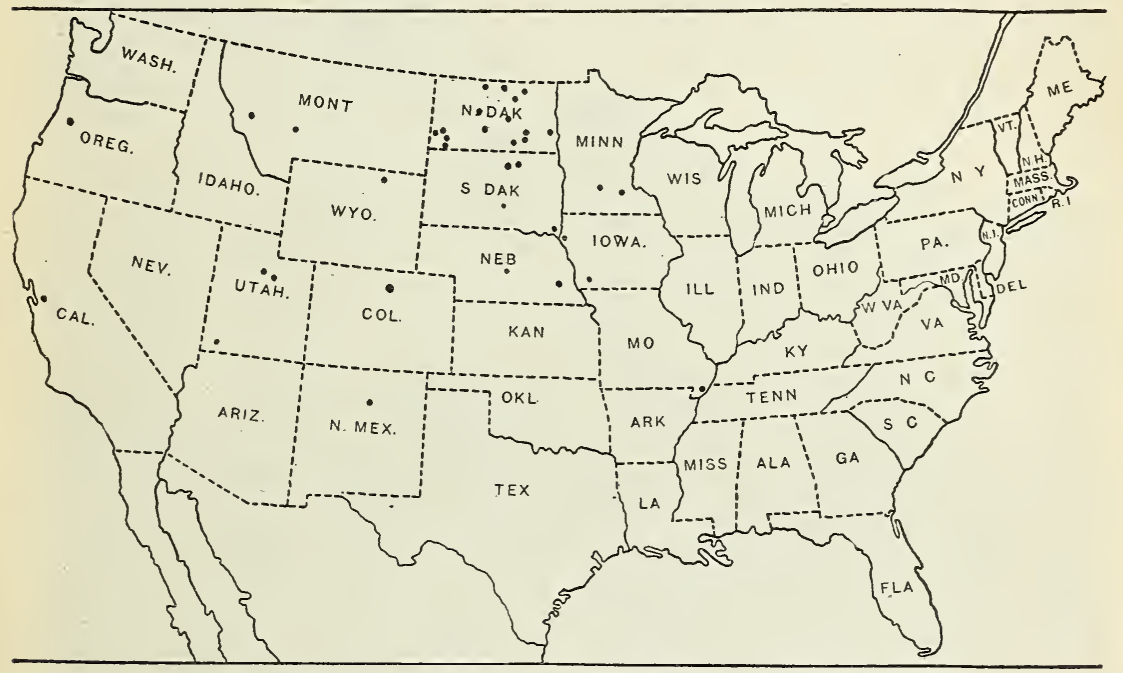

FIG. 2.-Distribution of the western grass-stem sawfly in the United States.

August 31, 1907, Mr. E. O. G. Kelly, then an agent of this bureau, noted a few wheat straws near Minot, N. Dak., that had been burrowed by the larvæ of Cephus.

In 1908 Messrs. F. M. Webster and G. I. Reeves found the larvæ of Cephus working in grasses in the Willamette Valley in Oregon. In the same year Dr. Fletcher again called attention to this insect, stating that in the previous autumn it had appeared in central Manitoba and in the southeastern part of Saskatchewan in much more serious numbers than ever before, and that the quantity of broken straws in the fields was causing the farmers some alarm. Mr. Norman Criddle of Aweme, Manitoba, a close observer and practical farmer, wrote to Dr. Fletcher that this fly had increased considerably during the last year or two, and was turning its attention to wheat and rye.

1 Fletcher, J. Report of the Entomologist and Botanist, 1896. Can. Dept. Agr. Exp. Farm, 1897. (See ग. 229-230.) 
August 20, 1909, Prof. H. B. Penhallow reported from Sherwood, N. Dak., that he had examined about a hundred fields from Minot, N. Dak., north to the boundary line and several miles into Canada and had found larvæ present in every field but one. He estimated the damage in these fields as ranging from 5 to 25 per cent of the crop, but spoke of one field about 27 miles east of Sherwood where the damage was said to have exceeded 66 per cent. R. W. Sharpe reported similar damage in the Red River Valley, near Fargo, N. Dak.

During 1911 and 1912 the writer found the species occurring freely in the native grasses in various parts of Utah, and as occasion offered

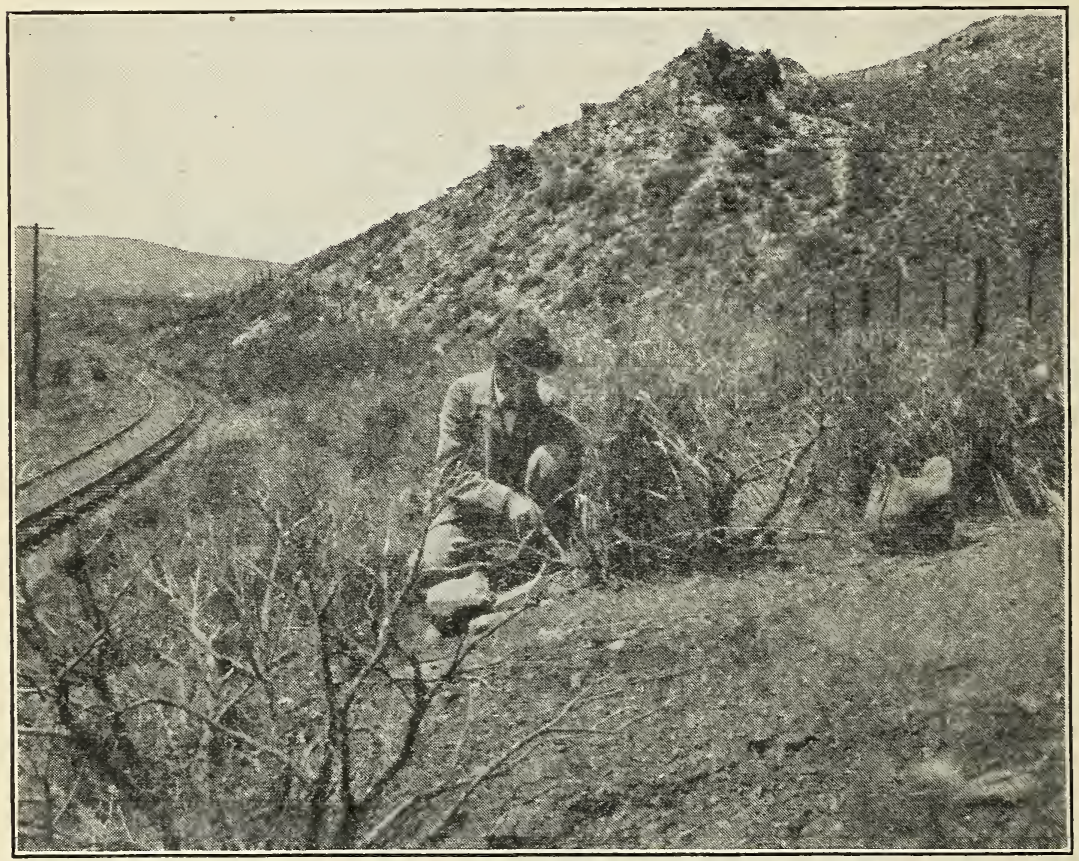

FIG. 3.-Plants of Elymus condensatus growing along the railroad right of way. The natural habitat of the western grass-stem sawfly in Utah.

the life history of Cephus was learned. Most of the facts in this paper are the result of this study. (Fig. 3.)

During the years 1913, 1914, and 1915 the writer has found this sawfly almost universally distributed over the Dakotas, Minnesota, Iowa, and Nebraska, feeding in Elymus, timothy, and Agropyron at Elk Point, S. Dak., in Agropyron tenerum near Chamberlain, S. Dak., in timothy at Edgeley, N. Dak., in Bromus inermis near Merricourt, N. Dak., in Elymus canadensis at Shakopee, Minn., in practically all these grasses near Sioux City, Iowa, and in wheat, timothy, and Elymus near Minot, N. Dak. It seems to have little choice in the various native grasses and is ready to attack any of the cultivated 
sorts provided the stem is sufficiently large for the larval gallery. As a rule, the larger, more robust stems are chosen for attack, especially in cultivated grasses such as timothy and Bromus. Blue grass and similar slender-stemmed species appear to be immune. It is a little surprising that a minute examination of Stipa viridula from New Mexico developed the fact that none of the stems of this robust grass were infested. This Stipa was gathered in northern New Mexico, growing in almost the same latitude as the Elymus condensatus near Pinto, Utah, where the fly abounds.

August 25, 1916, the writer, then at Pierre, S. Dak., receired instructions from the Bureau of Entomology to risit Bottineau County

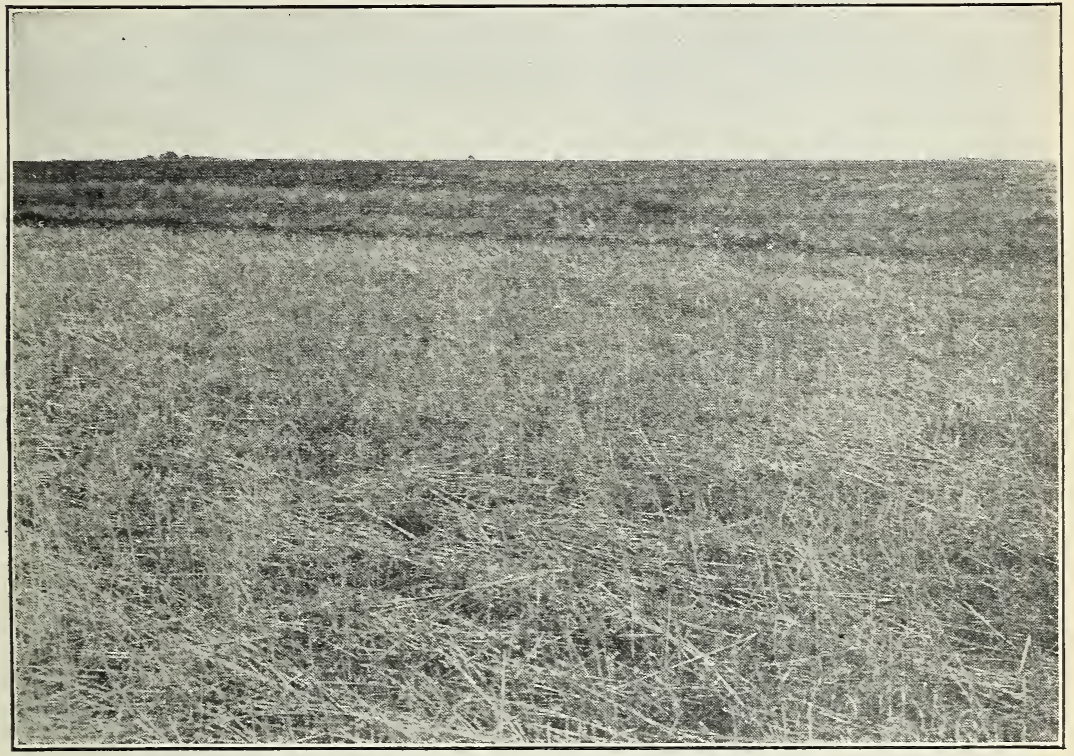

FIG. 4.- Wheat field of Thomas Yeam, near Souris, N. Dak., showing heavy damage done by the western grass-stem sawfly in 1916.

in North Dakota and investigate injury to wheat. It was believed locally that the Hessian fly was responsible for the damage that was being done. A very superficial examination of the injured fields proved beyond a doubt that the Cephus was present in large numbers and was doing an immense amount of mischief. Every field was infested, not only in Bottineau County, but in the adjoining counties of Benson, Pierce, McHenry, and Rolette. Near Souris, a few miles south of the Canada line, a large field of wheat on the farm of Thomas Yeam was fairly carpeted with the "straw-fallen" grain. (See figs. 4 and 5.) The loss from Cephus injury in this field was estimated at 60 per cent or more. Six feet of drill row here were taken at random and examined plant by plant. Forty-eight infested stubs were found, 
an average of eight to each foot of drill row. This would mean 150 to the square yard or about 726,000 larvæ to the acre. Higher counts were made later in this same field, so the average may be larger than stated. During April, 1917, Mr. Yeam's field was again visited and a random square yard marked out and counted. Two hundred and sixty-nine infested stubs were taken from this yard, which would mean more than 1,300,000 larvæ to the acre. Fifty of these stubs were opened and 47 of the imprisoned larvæ that had spent the winter within the straw were found to be normal and very much alive. The proportion of living individuals among the hibernating larvæ seldom falls below this ratio.

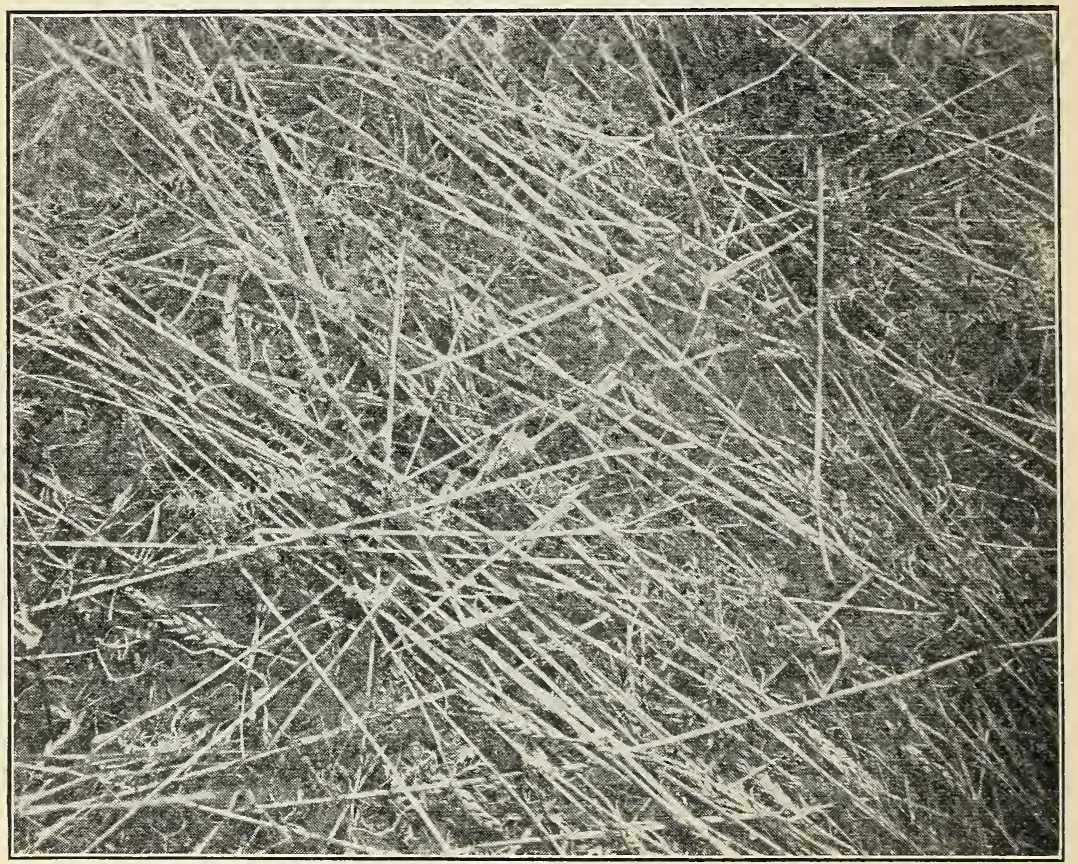

FiG. 5.-Bird's-eye view of wheat in Thomas Yeam's field, Souris, N. Dak. Ninety per cent of these fallen wheat stems have been mined by the western grass-stem sawfly.

The spring of 1917 witnessed a peculiar condition of things in Bottineau and the adjoining counties of North Dakota. The dry weather hindered the growth of both grasses and grains, so that when the adult Cephus began to appear in June there was almost no opporportunity for oviposition. Stems of Bromus from chance sods growing among wheat and on waste ground were filled with eggos. Young plants of spring wheat that had barely begun to joint were attacked and often contained as many as three and four eggis placed in the stem close to the ground. With a few strokes of the net 136 adults were swept from young wheat, so numerous were the flies at that time, In spite of the unfarorable oviposition conditions of that spring, the 
eggs appear to hare hatched and at harrest time the majority of the wheat stems had been bored and many were cut off at the base. Careful harvesting and the use of horse rakes sared a large proportion of what otherwise would have been a total loss. The infestation was much more general than in 1916 .

A somewhat hasty reconnaissance was made through north-central North Dakota in August, 1919, that it might be ascertained as definitely as possible just how the Cephus attack was progressing. A number of fields in Bottineau County were examined and found to be heavily infested. Most of these had been raked after harrest and it was consequently impossible to compute accurately the percentage of infestation. The numerous sawfly-inhabited stubs in the drill rows, however, proved the severity of the attack. It was roughly estimated that about 30 per cent of the grain had gone down in most of these fields as the result of Cephus work. This figure is probably very conservative.

It is conceded by many observers in that region that the injury during the year 1919 was greater than during any previous year since the study of this pest was begun. More fields had been seriously invaded and were injured to a larger extent than had before been observed. Even fields of durum wheat, hitherto believed to be nearly free from fly attack, were severely injured in 1919, if the statements of reliable farmers are to be accepted. The question of immunity of durum wheat will be discussed later in this paper.

It may be stated, howerer, that the farmers are profiting by past experience and have used horserakes in stubble fields to such an extent that the percentage of actual loss of grain has been reduced to a small figure. The quality of grain from the fallen straw is naturally somewhat below the normal, since the work of the larvæ in the stems produces some injury in the heads as they fill.

Cephus was found mining wheat near Hettinger in southwestern North Dakota, July 18, 1917. September 22, 1917, infested wheat was found near Mott, 30 miles north of Hettinger. In October of the same year many wheat fields in Towner and Cavalier Counties, in northeastern North Dakota, showed heavy infestation, although during the previous year it was difficult to discover more than a trace of Cephus presence in the wheat in this region. None was found in the vicinity of Fargo, although it doubtless occurs throughout the entire Red River valley.

A gathering of sods of Elymus canadensis sent to the writer from Charleston, Mo., during the summer of 1917 contained at least one larva of Cephus cinctus that had been boring the stem of this grass in that region. This locality is a little south of the latitude of Pinto, Utah, where this insect abounds. 
Roughly speaking, so far as is now known, the sawfly inhabits an area bounded on the north by a line far into Canada; on the east by the Mississippi River, or probably a little east of that: on the south by latitude $36^{\circ}$ : and by the Pacific Ocean on the west.

From the foregoing brief summary of its history it will be seen that Cephus cinctus is distributed orer an immense territory and that it constitutes a potential menace to the small grains throughout this rast area. As the acreage of native grasses is decreased from rear to year $b_{y}$ the bringing of wild lands under the plow, pests such as the sawfly will be forced to depend in an increasingly large measure upon the small grains and other products of the farms. On this account the injury caused by these formerly harmless insects bids fair to increase steadily. In the past the numbers of grass-feeding insects such as the one considered in this paper hare been gorerned mainly by the supply of food plants. A dry summer that retarded the growth of long-stemmed grasses would automatically reduce the numbers of the insects that lived within these grass stems and perhaps bring certain species to the point of extinction. It is easy to see how seasonal fluctuations in regetation would, to a large extent, either multiply or diminish the numbers of these insects.

Then again, the farmer, by introducing fields of grain into a region previously uncultirated, brings in conditions unknown before and invites the attack of these and other formerly harmless insects, making it possible for them to become a menace to his future. Such a study of life history as has been attempted in this paper is urgently necessary in order that control measures may be undertaken successfully when such insects become pests.

\section{FOOD PLANTS}

The various species of Agropyron and Elrmus, genera both of which are well represented in the West, appear to hare been the original hosts of the larre. Since their feeding habits hare been modified by changing agricultural conditions, the list of their present host plants, so far as known, stands as follows:

$\begin{array}{ll}\text { Elymus canadensis } & \text { Agropyron occidentale } \\ \text { Elymus condensatus } & \text { Agropyron caninum } \\ \text { Agropyron tenerum } & \text { Hordeum jubatum } \\ \text { Agropyron richardsoni } & \text { Bromus inermis } \\ \text { Agropyron smithii } & \text { Phleum pratense } \\ \text { Agropyron repens } & \text { Deschapsia sp. }\end{array}$

Calamagrostis spp.

Festuca sp.

Theat

Durum

Spelt

Rye

Barley probably should be added to this list.

Since the larva is wholly unable to more from one stem to another, it is rery obrious that the host stem must be large enough to afford both shelter and food during its entire growing period. Hence only the larger-stemmed grasses can be mined successfully by the Cephus 
larvæ. Occasionally an unusually vigorous plant of a slenderstemmed grass, like Hordeum jubatum, affords stalks with diameter sufficiently great to be attacked by Cephus.

Small grains, such as wheat and rye, readily serve as hosts to this insect, because they are of suitable size and the length of their growing season coincides with the growth of the larva. Even if harvest time should happen to come before the maturity of the larva, the reaping machine probably would sever the stem far enough above ground to leave the larva below the sickle cut, where it could house itself safely before the end of the season.

Judging the future by the recent past, it seems probable that this fly, before another decade is past, will be found attacking practically all of our native and cultivated grasses and most of our grains.

It must be remarked in this connection that up to the present time this species has confined itself entirely to the West and has been found in only a few localities east of the Mississippi River. Its choice of wheat for food has taken place, so far as known, only in North Dakota and western Canada, although it is probable that Montana wheat fields have been invaded. From present appearances its attacks probably will be confined to vegetation growing within the area where spring wheat is sown.

\section{THE EGG}

The egg of Cephus cinctus is, when newly laid, decidedly crescentshaped, glassy in appearance, milky-white in color, usually quite symmetrical, the ends of the crescent tapering and rounded. It is marked by very faint, short, longitudinal lines or wrinkles, placed without regard to order or pattern.

The size of the egg varies with the size of the female that produced it and measures from $1 \mathrm{~mm}$. to $1.25 \mathrm{~mm}$. in length. The greatest breadth is about one-third the length.

The covering membrane is hyaline and transparent. Although very thin and delicate it is sufficiently strong so that the egg may be safely lifted and moved by the aid of a fine brush. The egg always lies free within the stem of the host plant, either in the stem cavity or in a hollow excavated by the ovipositor of the female that placed it. This cell is always a little larger than the egg, so that it is comparatively an easy matter to remove the egg to a moist cell or elsewhere for study.

The number of eggs distributed by each female appears to vary but little. Dissections of a number of adults taken in the field and of others reared in captivity agree in most cases in giving a count of about 50 eggs in the ovaries, these eggs being, as a rule, equal in size and apparent maturity.

$150056^{\circ}-20-$ Bull. $841-2$ 


\section{DEVELOPMENT OF THE EGG}

After a number of trials it was found to be impracticable to rear the egg in situ, since it was next to impossible to maintain the proper moisture conditions within the stem. The method that finally was adopted, and that gave excellent results, was to remove the egg from the stem and place it in a minute drop of water within a small thin watch glass which was then immediately inrerted on a glass slip and sealed with a ring of water to prevent undue evaporation. This form of moist cell proved quite satisfactory and permitted continuous examination of the egg with a moderately high-power lens during the entire period of incubation. It was found necessary, in order to continue the requisite moisture supply during a period of several days, to invert over the sealed cell a larger watch glass and over this in turn a tumbler. In this manner evaporation was reduced to a minimum. It is altogether probable that the amount of moisture in such a protected cell exceeded that normally present within the grass stem, but in every egg treated in this way the incubation appeared to proceed naturally.

Temperature and moisture are, without any doubt, the prime factors that hasten or retard the egg development. The temperature maintained within the laboratory during the course of these investigations was much more equable than that in the field, where, as in Utah, the heat of the sun through the daytime, followed by a chilly night, must aiternately hasten and check development. The data given below, therefore, may only approximate what actually takes place under field conditions.

A few hours after the egg leaves the oviduct the milky-white contents of the egg which at first completely filled the envelope shrink a little from each end leaving a transparent space or vacuole. Gradually the interior mass of exceedingly minute particles coalesces until about the second day when a series of faintly discernible cells arranging themselves along a central axis begins to appear. Early on the third day the form of the larva can be dimly seen, the head being almost transparent and filling one end of the egg sac. The body is looped on itself, the cauda folded beneath the abdomen and extending forward nearly to the head. By the close of the third day the abdominal segments are usually well defined.

During the fourth day, in most cases, a spasmodic and intermittent heart beat may be noticed. These pulsations become more and more regular as the hours pass and during the fifth and sixth days the heart beats with much regularity at the rate of about 120 impulses per minute. At intervals, for some unknown reason, it may slow down to 75 beats, but soon resumes its former rate.

The head appears abnormally large at this time, but although its general outlines are well defined the brown jaws and eye spots are 
not yet visible. Over night, at the close of the fifth day, the jaws turn brown and the eye spots appear and darken. Usually, after the fourth day, the muscular system of the larva is in almost constant motion, shifting and adjusting, with the heart pulsating and the muscles moving, all clearly to be seen through the transparent membrane that serves as the shell.

The activity of the larva within the sac increases during the sixth day, and either on this day or the serenth it escapes from its confinement by a series of convulsive morements that rupture the delicate shell and set it free.

After the first day the egg changes shape, becomes intumescent, generally loses its crescentic shape entirely, and grows oval or reniform in outline.

\section{THE LARVA}

When it escapes from the egg the larva (fig. 6).possesses a very large head armed with a pair of powerful biting jaws, a weak, slender body, and a most rigorous appetite. It is rery active from the start and begins almost at once to feed upon the living parenchymatous tissue by which it is surrounded in the interior of the stem, excarating for itself a threadlike gallery both abore and below the spot where the egg formerly lay. The larva is at first nearly transparent and colorless until it becomes filled with the tissue on which it exists.

The body segments are strongly and clearly marked from the time the larva leaves the egg. The jaws are brown, three or four pointed, the points chisel-shaped, beveled on the inside edge. The brown face plate

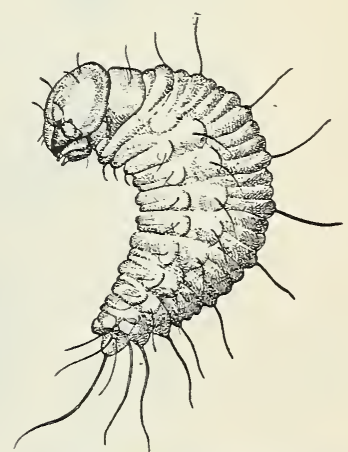

FIG. 6.-Western grass-stem sawfly: Newly-hatched larva. Greatly enlarged.

is filled with crossed bands of striated muscular fiber that actuate the powerful jaws which form the most important item of the domestic economy of the young Cephus. The caudal horn, by means of which the larra moves up and down in its gallery, is also brown and is armed, even in the first instar, with a series of stout bristles at the base of its cylindrical and squarely truncate extremity. The larra is footless, the position of the legs being marked by minute, rounded tubercles terminating in a few short bristles.

Although the primary excaration made by the larva may extend for a short distance above the egg cell, the general course of the progress is invariably downward. In its earlier stages of existence, at least, the larva traverses its gallery several times, swallowing repeatedly the same fragments of tissue that have already been devoured during the first excavation of the stem. Young larvæ are 
frequently found several inches above the lower end of the boring, moving through the solidly packed "sawdust." As the larra approaches maturity it is doubtful if it ventures into the upper and slender part of the stem, but it still reworks the frass farther down, enlarging the bore in places.

The number of instars is difficult to determine, owing to the larval practice, just referred to, of passing all the frass several times through the digestive apparatus. Nearly all the cast skins disappear completely under this treatment, only the heavily chitinized parts such as the jaws and caudal horn being recognizable in the burrow. Care-

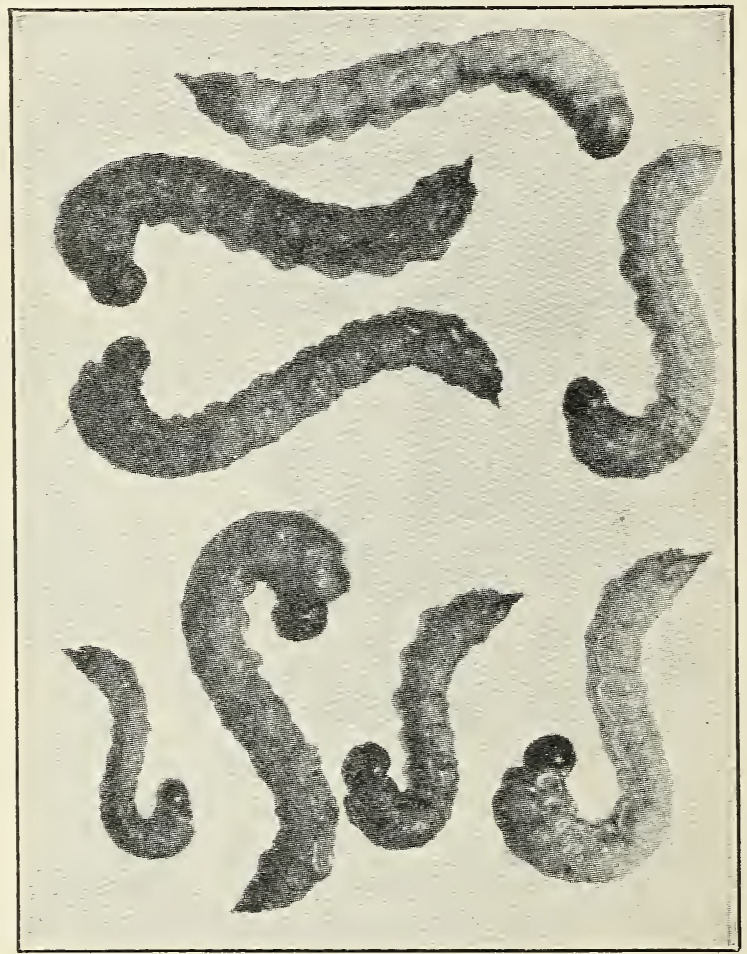

FIG. 7.-Western grass-stem sawfly: Mature larvæ removed from their galleries. Enlarged 4 diameters.

ful investigation of these fragmentary remains appears to establish the fact that there are four molts. The contents of innumerable stems have been examined with scrupulous care and with rarying results. In a few cases as many as four sets of jaws and in others four caudal horns have been found, mixed with the frass within the stems. Seldom were more than four sets removed from a single stem; usually only three were found. As is stated elsewhere in this paper, it is no uncommon thing to discover two and even three larvæ mining a single stem, although but a single individual can possibly reach maturity with the amount of nutriment contained in 
one stem. It is believed that the larva that finally reaches maturity has devoured its rivals. It is obvious that the remains of these superfluous individuals would naturally be counted when a census of exuviæ was undertaken and would complicate the result. But from the best evidence obtainable it is almost certain that there are five instars in the larval life of this species.

The length of the larval period is probably about 60 days, varying more or less with the warmth of the summer and the state of maturity of the host stems. The acceleration or retardation of the oviposition period owing to an early or late spring has much to do with the date of maturity of the larvæ, and possibly with the length of the larral period. August 29, 1911, at Kimballs, Utah, at an elevation of 7,000 feet, the writer found mature larvæ in stems of Elymus condensatus. The next year, at the same place, oviposition was beginning freely during the first week of July. The determination of the larval period is wholly inferential, based upon the findings in a series of stems (figs. 7 and 8 ).

The full-grown larvæ vary greatly in size, their growth being governed, as is usual in the case of such borers, by the quality and quantity of food consumed. Those living in wheat stems are much smaller as a rule than those found in rankgrowing grasses such as Elymus. Measurements of a series of individuals give variations of from 8 to $14 \mathrm{~mm}$. in length and from 1 to $2 \mathrm{~mm}$. in diameter.

When mature the larva always seeks the extreme base of the stem, where it soon begins its preparations for hibernation. Its first move is to cut a neat $V$-shaped groove entirely around and inside the stem, usually at or a little above ground

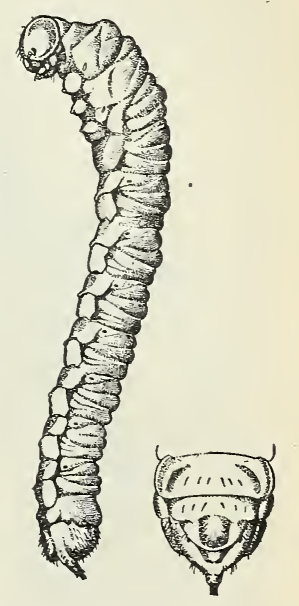

FIG. 8. -Western grass-steni sawfly: Mature larra. Enlarged 5 diameters.

level. This groove never severs the stem completely, but so weakens it that the upper stalk, swayed by the wind, will break off completely when dry, leaving a stub that is very characteristic of the work of this insect (fig. 5). In this simple manner the larva provides for the easy escape of the adult in the following summer. The length of the stub thus formed varies greatly. In Elymus condensatus the stub sometimes will project above the ground as much as 3 or 4 inches, while in other grasses, and especially in wheat, stubs easily can be found less than an inch in length in all.

Instances have been observed where two or more grooves had been cut inside the same stem, as if the larva had been uncertain as to the best place for severing the grass. After cutting its characteristic groove within the stem the larva forces a mass of the débris into the 
bore just below the groove and in this manner plugs the upper end of the stub that is to be left in the ground after the upper stalk has been broken away (figs. 9, 10, and 11). This dry frass in some manner is packed firmly into its place, perhaps by means of pressure rather than by being cemented with a liquid furnished by the larva, since the plug is readily penetrated by moisture. This is somewhat remarkable in view of the fact that an undue amount of moisture appears to have a disastrous effect upon the mature larva. One would suppose that these stubs, often wholly submerged in watersoaked earth for weeks at a time, would absorb, during the long period of hibernation, a fatal amount of dampness from the rain or melting snow. But there is no evidence that this ever happens.

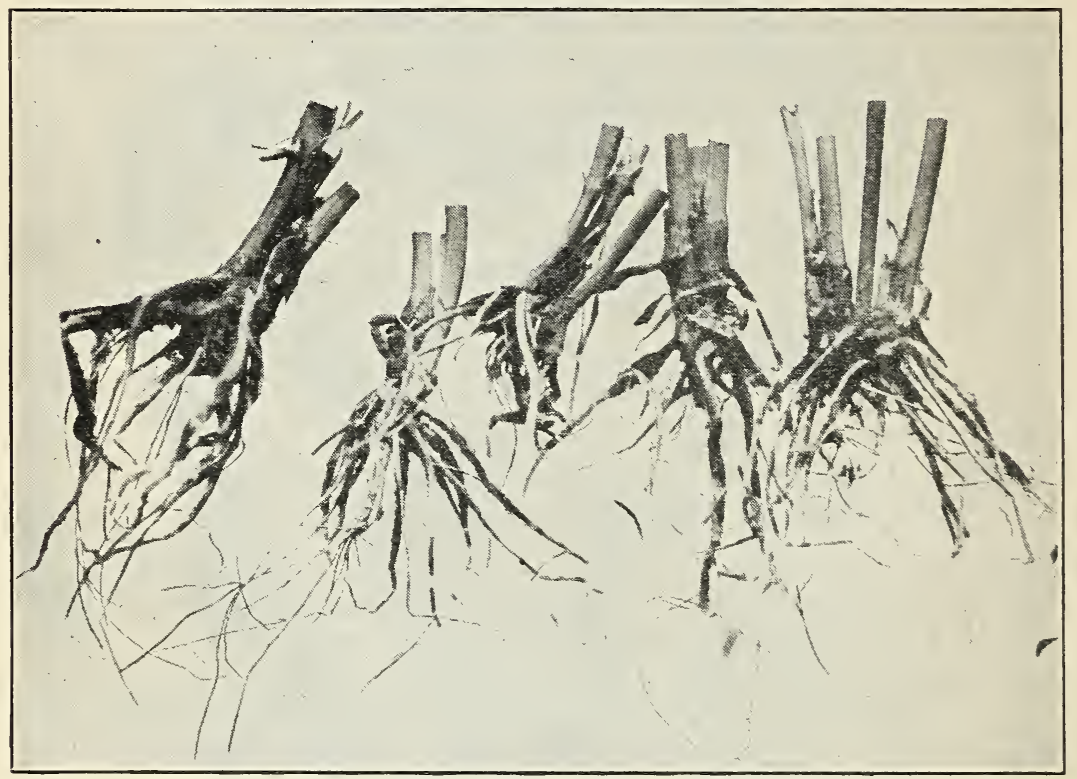

FiG. 9.-Western grass-stem sawfly: Infested wheat stubs from Bottineau County, N. Dak.

September 16, 1911, one of the larvæ was removed from the hibernation chamber and placed in a small vial, still inclosed within the silken tube or cocoon, which was unbroken. For months this larva remained passive and motionless except when the vial was exposed to bright sunshine. Because of the light or heat, or both, when placed in the sunlight it would become active at once, and travel up and down within its cocoon in its efforts to escape. January 20, 1912 , to prevent the air in the vial from becoming too dry a small drop of water was introduced and the vial again corked tightly. An hour later it was noticed that the silk tube had collapsed and the larva within was limp and apparently dying. The surplus moisture was removed quickly, whereupon the larva revived almost at once. 
If the same amount of moisture had entered the stem where the larva was hibernating it probably would have caused its death. This experiment, taken in connection with others that were not so directly conclusive, seems to prove that the porous plug in the stub must prevent in some way the admission of an undue amount of moisture into the chamber below, although water readily penetrates it.

The gallery below the plug is always entirely free from débris, forming a hibernation chamber and later a pupation cell. Within this chamber the larva lies with its head up and usually pressed against the barrier at the top, always on the alert to retreat downward at any sign of disturbance. It descends by alternately flexing and straightening the body, bracing itself first by the jaws, then by the caudal horn as it hitches its way down In ascending, the caudal horn is thrust against the side of the gallery or the cocoon, the body is straightened, the jaws obtain a purchase to hold the distance gained, when the body is again drawn up until the caudal horn is applied to the side wall for another push.

Latein the summer or during the autumn the larva spins for itself within the hibernation chamber an almost transparent tube of filmy silken

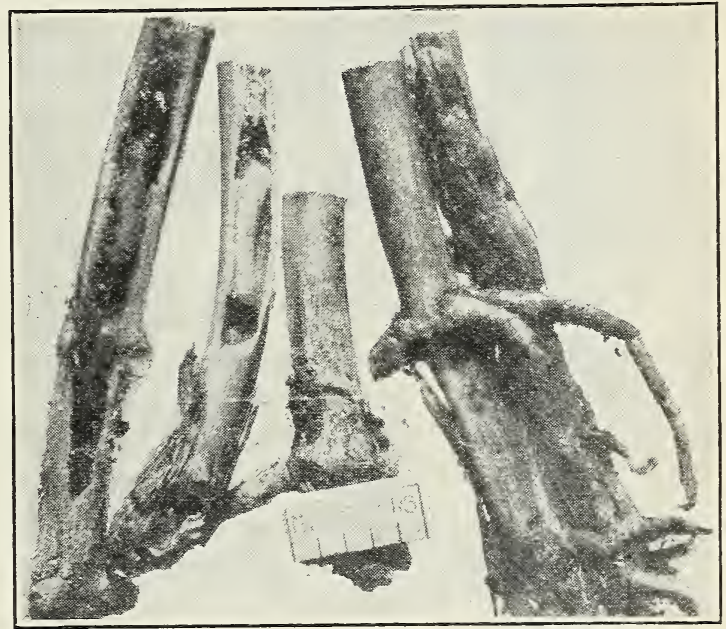

Fig. 10.-Western grass-stem sawfly: Infested wheat stubs, enlarged 3 diameters, the two left-hand ones opened to show hibernating larvæ in situ.

tissue. This silk tube is sometimes several times the length of the larva, is closed at both ends, and is free from the sides of the chamber, so that often it can be readily withdrawn entire. When first constructed this fabric is comparatively strong and pliant but after some months it grows more brittle and is easily ruptured. As a rule it remains intact until the emergence of the adult. Even the presence of half a score of parasitic larvæ often fails to wreck the delicate structure during the winter.

The longevity of the sawfly larvæ is remarkable and is worthy of mention. September 8, 1911, a number of stubs of Elymus condensatus containing Cephus larvæ were gathered and set upright in sand within doors. From time to time this sand was moistened but finally was allowed to stand perfectly dry. During October, 1912, 
these stubs were examined and a number of the inclosed larvæ were found to be still liring, active, and unchanged. Four months later, 17 months from the time they were gathered, they were still alive and feebly active. Infested stubs of the same grass taken during September, 1912, and treated in the same manner, contained at least one living larva on February 23, 1916, 3 years and 5 months later. The others had nearly all died within about 30 months of the time they were gathered. It is possible that the lack of necessary moisture may account for the retardation of these captives. However, the same retardation of derelopment has been noted in the field. Inhabited stubs of the previous year's

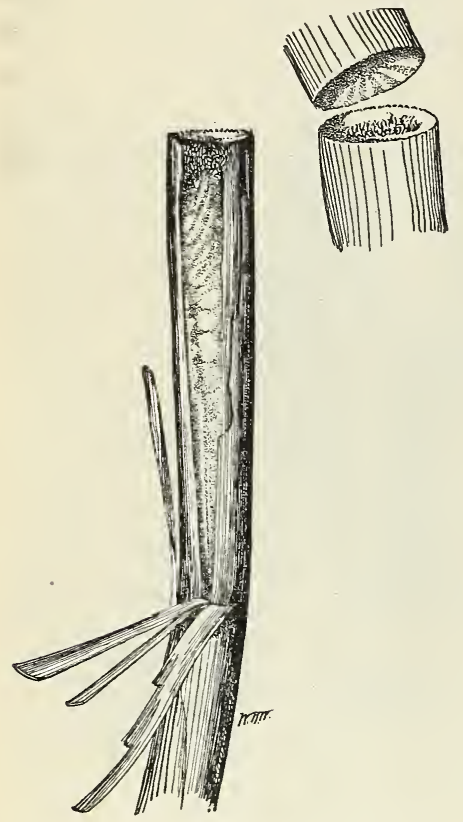

FIG. 11.-Stems of wheat grooved internally by larvæ of the western grass-stem sawfly. growth of grass and grain not infrequently have been found, containing larvæ that were to all appearances entirely normal and active. It appears more than probable that in this manner the perpetuation of the species is assured in case of unfavorable seasons.

During the winter the larvæ are, of course, frozen, or are chilled into immobility and show no signs of life when disturbed. As soon as the earth warms in the spring they again grow active and move freely up and down within the limits of the silk-lined hibernation chamber until the time of pupation arrives.

\section{THE PUPA}

The pupa when first formed is milk-white, slender, and somewhat longer than the larva from which it was derived. Its average length is not far from $12 \mathrm{~mm}$. and its breadth is about $1.5 \mathrm{~mm}$. At first the pupa lies motionless within the silken pupation chamber or cocoon (fig. 12) for probably a day or two, after which inactivity it again becomes animated. When disturbed it will endeavor to escape the threatened danger by moving either up or down the tube, hitching itself along in much the same manner as the larva but going a lesser distance with each effort. Like the larva it is almost always found with its head pressed closely against the plug of frass at the upper end of the chamber. In a few cases pupæ hare been discovered heading downward in the stem. It is doubtful if these can reverse 
their position, but the adults which issue are probably agile enough to turn about and escape.

The duration of the pupal period is not known certainly, but is believed to be very brief, not more than a week at the most. After the first day the legs and body darken until they become a lustrous black within the transparent, almost invisible filmy membrane in which they are inclosed. This membrane is often laching and may occasionally be destroyed by the movements of the pupa within the chamber.

When fully mature the pupa changes within the cell to an active adult. This adult remains imprisoned until some unknown impulse compels it to force its way upward through the plug of frass placed at the upper end of the chamber by the larva 9 months before. The writer, by splitting stubs of grass or grain in June, has liberated adults repeatedly, which, when free, were able to take instantly to wing without any preliminary process of drying or other preparation. These adults were evidently resting, in perfect condition, waiting for some secret signal from the outside world before taking the final step for liberation.

A very few die within the cell, possibly because of lack of vitality needed to break through the stopper of frass above them. In cases where the girdling of the stem was inefficiently done, so that the grass stalk did not break off during the winter season, the adult dies as a matter of course, since these flies apparently are not fitted with jaws capable of biting through the woody stems of dry grass.

\section{THE ADULT}

The adult Cephus cinctus is a beautiful insect with a polished black body marked by three prominent yellow bands across the abdomen. The legs are yellow and the wings smoke-colored.

The description, by S. A. Rohwer, follows:

Length 7 to $12 \mathrm{~mm}$. Head shining, polished; anterior margin of clypeus truncate with angles prominent and sometimes slightly denticulate; antennæ usual for the genus; thorax shining but with setigerous punctures on scutum; sheath nearly parallel-sided but a little broader at base, apex truncate with corners rounded; hypopygidium rather narrowly subtruncate apically. Black marked with bright lemon yellow, amount and extent of yellow markings varying greatly; head of female usually black but more rarely with face entirely yellow or having yellow spots; head of male black but always with yellow on face; thorax black, the upper angle of mesepisternum, parapteron, and scutellum (usually) yellow; legs yellow with coxæ, trochanters (occasionally both of these having yellow marks), bases of femora more or less, apices of ti’iæ and tarsi sometimes, black; hind tibiæ and tarsi sometimes reddish yellow; abdomen black, spot or band on second tergite, band on third, fifth, sixth, and eighth 
tergites and lateral margins of tergites yellow, the size and extent of these markings varying and occasionally the fourth tergite having a yellow band; wings fuligirous, venation dark brown, costa and stigma yellow.

The female is noticeably larger than the male, and in the field is captured much more easily.

The characteristic attitude of the adults of either sex while at rest is to lie flat against the grass stem, head downward, the body closely appressed to the stem, the legs not spread but stretched in line with the body while the body itself is concealed behind the closely folded, smoke-colored wings. The ease with which such a strikingly colored fly, while in this position, can escape observation, is remarkable. During the chill of the morning and after sundown this attitude is universally assumed. When basking in the sun at midday, on the warm side of a grass stem, the fly is much less compact, with the wings partly spread and the legs outstretched in order to absorb the utmost of the warmth. Like most Hymenoptera, this species is very partial to sunshine and rarely is seen abroad on a cloudy day. In fact, in cloudy weather it is not easy to find these flies at all, unless one is entirely familiar with their habits.

They are weak fliers and seldom travel to any great distance at one time. In Utah they commonly move about among the plants of bunch grass, making short flights from tuft to tuft. If the wind rises or the sun goes behind a cloud they promptly disappear until conditions again become satisfactory. The writer has never taken the adults at any great distance from their breeding places.

Their hovering flight is peculiar, the swaying motion of their bodies in the air reminding one of certain tipulid flies during their mating air dance. They often hover for a long time to the windward of a grass plant without alighting, seeming to enjoy the motion. The males are on the wing much more than the females, but neither sex will remain in the air while the wind is strong or when it is cool. The adults are not at all timid and can often be readily taken from the grass stems with the fingers. When conditions are favorable for her the female is usually too intent on oviposition to be easily annoyed but if disturbed beyond endurance she quickly disappears, her dark color and slender body enabling her to vanish completely among the vegetation.

Copulation is very brief, usually lasting less than a minute. No notes were made on the attitude assumed during the operation.

The species is single brooded, the adults appearing during the spring and going out of existence some time about midsummer.

The earliest individual met in Utah was taken in a net April 26, 1910, in an alfalfa field. Adults have been seen in the mountains late in July and they probably linger longer than that, ovipositing in such green grass stems as they can find. Near Kimballs, in Utah, September 8, 1911, the writer took very young larva from stems of 
Elymus condensatus, growing from plants that had been browsed by cattle and had thrown up fresh green stalks.

Mr. Norman Criddle states that in Canada the adults appear during the second week in June and may be met with until about July 10. Occasionally they may be found feeding on flowers. Doctor Fletcher has taken them in Canada on flowers of the tumbling mustard. It is unquestionably true that the time of their appearance and the length of adult life are both largely governed by climatic influences and vary with the season.

When confined in emergence tubes or other limited places the males develop savage instincts and attack each other without mercy, using their jaws freely to snip off the antennæ, and, in some cases, the legs of their rivals. Singularly, very few of the females confined with them are thus mutilated.

\section{OVIPOSITION}

Weather conditions have always been an important factor in controlling the oviposition of very many of the Hymenoptera, and they are of particular importance in the case of the Cephus. These flies go in to hiding when the day is dark, damp, cool, or windy. Only on bright, warm, still days are they to be found busy with the operation of placing their eggs. In Utah, where the first studies of their habits were made, the mornings and evenings are chilly as a rule, hence the activity of these flies is confined to the hours near midday. They are everywhere the most active between the hours of $10 \mathrm{a} . \mathrm{m}$. and 2 p. m.

The swaying of the grass and grain stems in the wind appears to be a hindrance to them in alighting and ovipositing. A gentle breeze will of ten keep them hovering for several minutes to the windward of their goal, while a sudden mountain gust is apt to put an abrupt end to all efforts for the balance of the day. Their actions are controlled by unknown factors, for sometimes on a still, sunny day they will spend much of the time roosting on the stems, while again, under apparently the same conditions, they are constantly in motion, flying and hovering a long time before alighting.

While the female is poised in the air before a sod of grass or grain she is evidently busy selecting the particular stem in which she hopes to oviposit. Once she has chosen and settled, she seldom changes to another stalk, although she may halt at several places on a single stem and attempt oviposition at each pause. Occasionally, after a hasty examination, she may again take to wing and make another choice. Repeated observations seem to have established the fact that one of the chief requisites of a proper stem is that it shall not yet have put forth a head. In all the countless instances where oviposition has been observed, the female has never been known to choose a stem with a head. 
When she has made her selection of a suitable stem, the female usually alights about half way up and runs briskly to the upper end, halting almost imperceptibly every few steps. The gait of an ascending fly is so characteristic that it determines with much certainty if the individual is a female intent on oviposition.

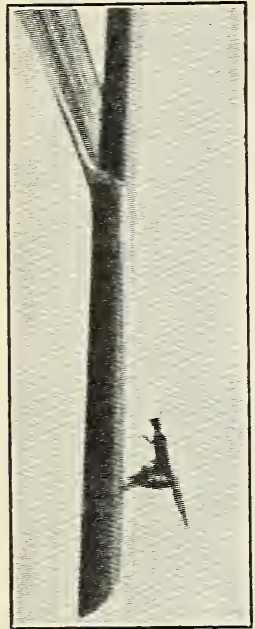

FIG. 13.- Western grass-stem sawfly: Fema?e oripositing. $A$ bout life sizc.

Arriving at the apex of the stem, after a careful survey of its condition, she frequently makes an elaborate toilet, preening herself most carefully, until she is in perfect condition. She then descends, exaggerating slightly the hesitating step by which she had ascended. The antennæ are held horizontally in front of the head as she moves, and she occasionally touches the surface of the stem with their tips. There is none of the rapid antennal ribration so common among the smaller chalcids and many other Hymenoptera. She gives no evidence of being in search of any particular point, but goes straight down the stem. When satisfied that she has gone far enough she halts abruptly, usually an inch or less above the second node from the top of the stem, slowly arches her abdomen and clasping her hind pair of feet around the stem as far as they will reach begins to drive the saws into the hard outer tissue. Figure 13 shows the attitude taken at this time. These saws are exquisitely fashioned, curved like a scimitar, double, very thin with serrated edges. (See fig. 14.) They are used to split the outer coating of the stem rather than to cut it, and they make an opening so exceedingly small that it is almost impossible to find the scar after the wound has healed. These saws are gradually forced into the stem, the operation occupying a minute or more. In the field the female always

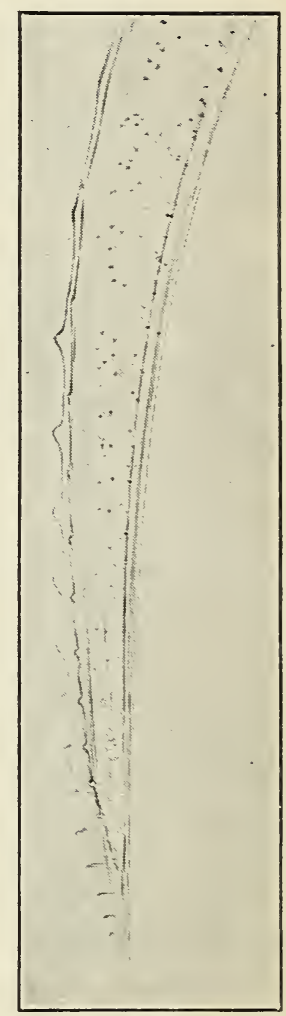

Fig. 14.-Western grass-stem sawfly: Saws, greatly enlarged. heads downward during oviposition and the curve of the saw blades brings them, when fully inserted, in a line parallel to the axis of the stem. They are frequently partly withdrawn and their direction slightly changed. When the stem is in proper condition the saws are thrust in several times, as far as they will go, then are withdrawn, 
the dorsal part of the pygidium being used as a fulcrum to extract them. They are inserted again, this time often with a twisting motion as if trying to enlarge the opening. They are finally forced in as far as possible, as is evidenced by the tenseness of the rear legs straining at the stem, and are held in this position for half a minute or more. This is probably when the egg is deposited, the insect standing practically motionless except for a slight vibration of the antennæ.

A laboratory note may be of interest, giving in detail some of the facts that have been mentioned above:

June 5, 1912. The adult Cephus were emerging freely from the Elymus material brought from the mountains, and it occurred to me it might be possible to secure some views with the camera if they could be induced to oviposit. Several females were observed attempting oviposition in the dry stems from which they had recently emerged.

A green stem of Elymus was planted in a tumbler of wet sand and the camera focussed on this stem about midway. After a few trials I discovered that this stem must be short and headless.

The females were taken from the cage and placed, one at a time, on the damp sand in the tumbler. Their first act in every case was to spend a long while drinking eagerly of the water held in suspension by the sand. A few of them sipped water for as much as half an hour before they could be induced to leave. When guided to the base of the Elymus stem they would usually ascend without a moment's hesitation. Once started they would go to the very top and there would either preen themselves interminably, or would wheel and descend with the usual cautious, hesitating gait, a few steps at a time. When part way down, without apparently choosing any especially suitable spot, the abdomen would arch and oviposition would begin. Sometimes these efforts were plainly failures, but some of the flies would sink their saws well into the tissue of the stem and stand for a number of seconds motionless, thus affording an opportunity for the camera.

Much time was lost to-day because of the exasperating neatness of these insects. Each one would brush herself over and over again with the most minute exactness and no amount of urging would avail to shorten the process. The same careful preening has been frequently observed also in the field.

Several life-size views of these flies were obtained to-day by the above method, views that would be impossible in the field because of the almost constant motion of the limber grass stems. Several of the females became confused to-day when compelled to remain on a certain part of the grass stem during oviposition, and faced up the stem instead of down as they invariably do, normally.

When busy with oviposition they seem oblivious to whatever is going on around them, and the writer has repeatedly watched, through a half-inch triplet, the female manipulating her saws. Close observation did not annoy her in the least when the lens was carefully handled, and she paid no attention to the proximity of the onlooker. Under the closest scrutiny it is impossible to determine just when the egg is passed into the stem. It is probably at the time when the female stands motionless after the saws have been driven in to their full length.

The function of these saws appears to be twofold. At Pinto, Utah, in June, 1912, the writer found that the eggs were invariably placed 
in a cell hollowed in the solid parenchyma of the stem of Elymus condensatus, this cell being a little larger than the egg. Besides piercing the stem, the saws are also of use in excarating this egg cell, in case such a cell is needed. At Kimballs near Salt Lake City, in the same grass, the eggs were nearly always placed in the hollow part of the stem, lying free in the central cavity.

Normally but one egg is placed in each stem. Howerer, no attention is paid to previous oviposition and as many as five eggs hare been taken from a single stem. As is stated elsewhere, only one of these larræ can possibly survive until fall, so this multiplication of eggs simply means economic waste for the Cephus.

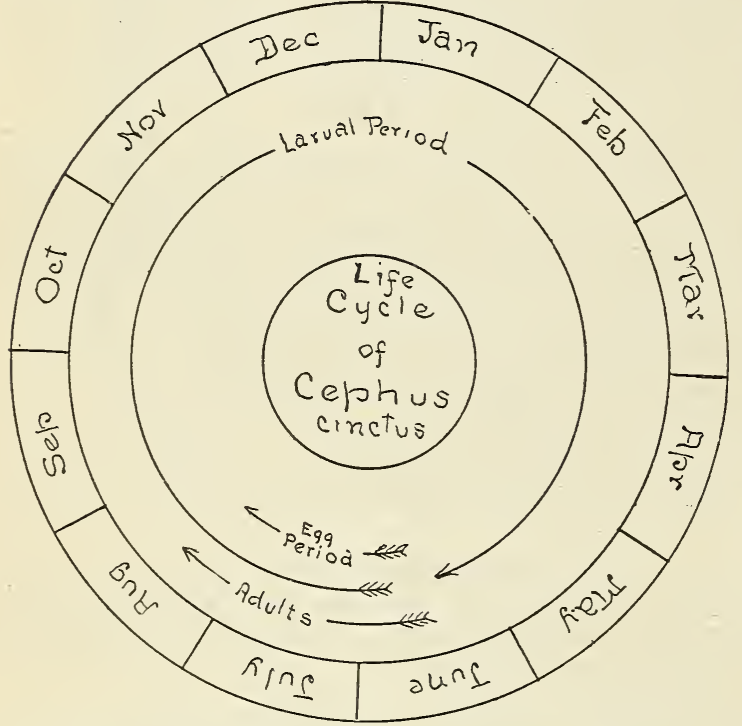

FIG. 15.-Life-history diagram of the western grass-stem sawfly.

The date of oviposition varies with the latitude and the altitude. At Pinto, Utah, on the edge of the desert country and with a low altitude, newly hatched larvæ were found June 14, 1912, while at Kimballs, 350 miles north of Pinto and with an altitude of 7,000 feet, oviposition was beginning during the first week of July in the same year.

Mr. Criddle states that in Canada most of the eggs are deposited during June. The date of oriposition in the Dakotas and in Minnesota is unknown. (Fig. 15.)

\section{KEY TO THE NORTH AMERICAN SPECIES OF CEPHUS}

Through the courtesy of Mr. S. A. Rohwer of the Bureau of Entomology a key for the determination of the known species of the genus Cephus occurring in North America is here presented.

Stigma and costa dark brown of a uniform color; mesepisternum black; femora black; apical tergite and venter black; face and scutellum black (face of male with yellow spots) ..................................... pygmaeus Linnaeus. Stigma in greater part and costa yellow; mesepisternum with the upper angle yellow; apical tergite and usually the venter in part yellow; femora usually mostly yellow; face and scutellum of female usually black but occasionally with yellow

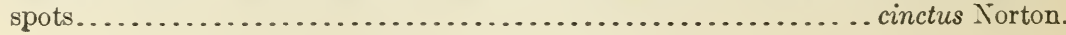




\section{NATURAL CONTROL}

In the usual scheme of things an undue increase of insect pests is controlled naturally by parasites that take a heary toll of their hosts and prevent their multiplication. Under normal conditions, when the Cephus cinctus existed wholly in grass stems, the larvæ were attacked with varying success by two or more species of parasites that destroyed numbers of them and kept them within reasonable bounds. Since the fly has begun to change its habits and to subsist on wheat and other small grains to a certain extent, these parasites apparently have not yet learned of the change and are confining their attacks, as heretofore, almost entirely to those larvæ that they find in grass stems. A very few parasites have been taken from infested wheat stubble, and there is little question but that in course of time the busy little parasites will hunt their prey in the grain stems and do their share in helping to control this pest.

The most common parasite found everywhere in the grasses is Pleurotropis utahensis Cwfd., a beautiful little bronze-green chalcid that was reared by the writer from numerous larvæ taken near Salt Lake City, Utah, from Cephus hibernation cells. This species appears to kill the larva only after it has formed its hibernation cell. It is gregarious and seldom or never attacks its host singly. As many as 12 of its larræ have been taken from a single cell, but 5 or 6 is a more common number. These larvæ are white and measure from $2.5 \mathrm{~mm}$. to $3.5 \mathrm{~mm}$. in length. They are somewhat active and travel slowly about the cell when mature. They are often found

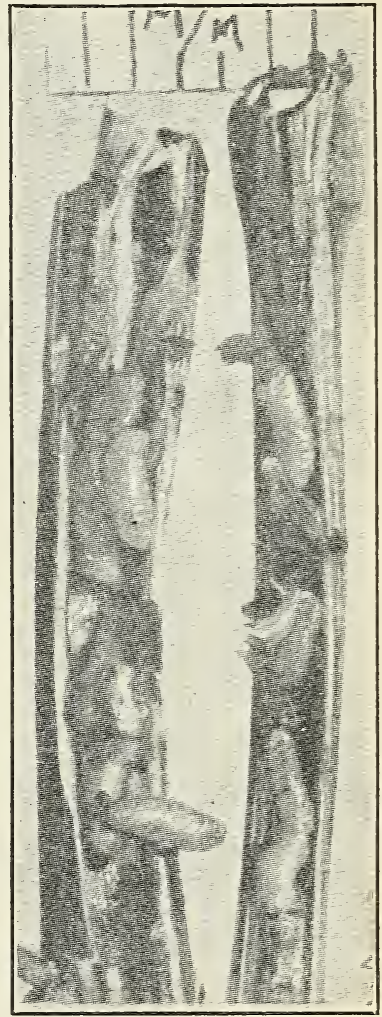

FiG. 16.-Larvæ of Pleurotropis utahensis, a parasite of the western grass-stem sawfly, in situ. crowded together in one end of the cell, but when disturbed will scatter about the chamber (fig. 16).

Although this species is widely distributed and propagates in numbers it appears to destroy but a small percentage, possibly 10 per cent of the Cephus larvæ in the native grasses of Utah. In Bottineau County, N. Dak., it attacks the sawfly very freely in Bromus and timothy, and in some localities has killed more than 50 per cent of the Cephus larvæ. Indeed, it and one other parasitic 
species are so numerous in these roadside grasses that it would seem poor policy to recommend the cutting of the grasses in midsummer as a measure of Cephus control. As has been stated, few parasites have been found in stems of wheat, but, without doubt, they will learn very soon of the presence of Cephus in grain fields and will adjust their habits accordingly.

A braconid, Microbracon cephi, recently described by Mr. A. B. Gahan, ${ }^{1}$ also attacks the larræ in grass stems, kills them before maturity, and spins a gray parchment-like cocoon within the gallery, generally near its lower end. This cocoon is truncate at both ends, its disklike extremities completely filling the bore. The adult escapes by biting an opening through the stem in the vicinity of the cocoon.

\section{ARTIFICIAL CONTROL}

From the foregoing sketch of the life history of the western grassstem sawfly it seems obrious that this pest will have to be attacked while it is in the larral state. The egg and adult stages are both brief and are clearly beyond the reach of control measures of any sort. For nearly 11 months the insect exists as a helpless larva, protected only by the grass or grain stem within which it lives. If this stem could be destroyed, the larva within would perish.

The first remedy that occurs to the farmer or the student of field conditions is the burning of the stubble in the autumn or spring. It would seem a rery simple matter to set fire to the stubble and destroy at least the majority of the sawfly larvæ that are hibernating in it. But when one begins to examine the infested fields it is found that the inhabited stems have been cut at the ground level or below so that it is often necessary to brush away the earth in order to find the stubs containing the larræ. So little heat is generated when stubble is burned that these subterranean stems could not possibly be harmed by the quick passage of the flames.

In 1907 Mr. Norman Criddle, in Manitoba, wishing to make a thorough test of this particular remedy, spread a layer of straw sereral inches deep over an infested area in a wheat field and set the straw on fire. More heat was produced than stubble alone could possibly make, the surface of the ground being too warm for the hand after the fire had died down. Eren after this serere treatment it was found that, as far as could be learned by a minute search, not a single larra had suffered. They had simply retreated to the lower end of the hibernation cell and "kept cool."

Another fact must be noted in this connection. When a field has been damaged seriously by the sawfly, the stubble remaining to feed a running fire is of necessity more scanty than in an uninjured field

I Gahan, A. B. Description of a new hymenopterous parasite (Braconidr). In Proc. Ent. Soc. Wash., จ. 20, no. 1, p. 18-19. Jan., 1918. 
and consequently it would be exceedingly difficult to burn such a field even under the most farorable conditions.

In Utah the bunch grass, Elymus condensatus, is much infested by this same fly and frequently is burned by fires that sweep the mountain side. This Elymus forms dense sods, with stems often more than 3 feet in length, and the heat from its combustion is great. The writer has examined a large series of burned sods and has seldom discovered any injury to the larræ from the fire.

These facts would indicate the futility of burning the stubble as a control measure.

Although it might seem possible to decrease the numbers of the fly by mowing roadside and fence-row grasses during July, thus destroying the larvæ always present in the stems of these grasses, careful study has proved that a large percentage of the larvæ in these grasses is parasitized and therefore it would seem unwise to take steps that might diminish the number of parasites. Without any doubt grain fields in North Dakota and Canada are invaded regularly by sawflies that issue from grass growing along their borders. Still, because of the multiplication of useful parasites from this same grass it is probably inadrisable to mow the grass in midsummer.

Deep plowing, 5 to 6 inches, is perhaps the best remedy for the sawfly that can be suggested at present. It is much easier to advise this than to put it in practice. In almost every plowed field in any part of the country each furrow is marked by a row of stubble projecting from the inner edge of the furrow slice. Unless the stubble is turned squarely upside down, burying it at least 5 inches, the resulting surface at the same time being compacted by harrowing or rolling, the flies will be able to escape with ease from beneath the ground.

In the fall of 1916 the writer buried four lots of infested stubble in different depths of earth sifted and compacted by jarring. These were buried, one at 3 inches, one at 4 , and 2 at 6 inches, in glass jars, 10 stubs in each of the first two, 20 in the other two. August 6, 1917, these cages were examined with results as follows:

Under 3 inches of earth all adults emerged.

Under 4 inches 1 larva died, all others emerged.

Under 6 inches 1 adult died in the cell, 6 larvæ also died, 2 active living larvæ still in the cell, all other adults emerged.

Under 6 inches 7 larvæ died in the cell, all other adults emerged.

Lumpy soil in the field might make it easier or harder for adults to emerge than fine soil in a jar, and this point might be difficult to determine.

Cultural conditions in North Dakota are not favorable for burying the stubble by plowing. Spring wheat is followed in many cases by winter rye which is disked into the wheat stubble after harvest. This 
procedure leaves all the infested stems of wheat on the surface, and nothing could be more favorable for the escape of the adult flies in the following spring. The wheat stubble seems to be necessary to hold the winter snow for the protection of the young rye, hence the farmers seldom or never plow the stubble under before sowing the rye.

Previous to the year 1919 it had been stated with much confidence by men who were known to be good observers that durum wheat was nearly immune from the attacks of the sawfly. On the strength of these statements county agents were inclined to recommend a modification of ordinary farm practice, at least to the extent of barring from that region Fife and Marquis and the softer-stemmed wheats in the hope that by this means the work of the sawfly might be checked and a more certain harvest assured. It was readily seen that an immune wheat would solve the problem of the sawfly.

Observations made by the writer during the month of August, 1919 , and recorded on an earlier page of this paper, included in their scope an inquiry into this question concerning the immunity of durum wheat. Farm work was too far along at the date of this visit to permit of effective field work to settle the matter definitely, but several farmers informed the writer that durum had suffered severely that year, although not as much as either Fife or Marquis. These reports must be accepted at their face value since the agreement on this point was general.

The immunity of durum may vary from year to year and is possibly based on the relative dates of the appearance of the adult Cephus and the rapidity of growth of the young grain. The stem of the durum wheat is more dense and unyielding than that of other wheats, and if a warm rainy spring should hasten its growth it might prevent the sawfly from placing many eggs. A number of unknown factors enter into this problem that hinder its complete solution at the present time.

\section{CEPHUS PYGMAEUS L.}

In certain parts of the country the occurrence of Cephus cinctus appears to have been confused with that of its congener Cephus pygmaeus, a sawfly stem-borer that was probably imported from Europe only a few years previous to the first mention of Cephus cinctus in the United States. The habits of the two species are so similar that a brief synopsis of the life history of Cephus pygmaeus is given herewith together with a condensed description of the same insect.

As far as is now known the imported species does not yet occur west of the Mississippi River, while the western grass-stem sawfly has been found for the most part only west of the same river.

C. pygmaeus was first observed in 1887 in the vicinity of Ithaca, N. Y., and in 1889 Prof. J. H. Comstock published ${ }^{1}$ an account of its 
life history as worked out by himself. From this bulletin the following summary of its habits and appearance has been compiled.

The adults, in the latitude of Ithaca, appear during the month of May and at once begin oviposition in the stems of wheat, just as the grain is jointing. In the majority of instances the eggs are placed above the third joint, and the larval gallery extends from the point of oviposition, or a little above, to the extreme base of the plant. By the time the wheat is ready to cut, early in July, a large majority of the larvæ have descended to a position below the level of the reaper cut and are safe from removal with the harvested straw. A week later nearly all the larvæ have girdled the stems within and part have already spun the silken lining of the hibernation chamber.

Cephus pygmaeus is a well-known species in Europe and has been described by both English and Continental writers. In France it has been considered a very serious pest. and is said to attack both wheat and rye.

\section{DESCRIPTION}

Adult shining black, banded and spotted with yellow. Length of male $8 \mathrm{~mm}$, of female $10 \mathrm{~mm}$. Head large with prominent eyes; three ocelli near summit. Antennæ inserted on front nearly opposite middle of compound eyes, and composed of 19 or 20 segments. Wings transparent, iridescent, somewhat smoky, with costal margin yellow toward base. Mouth-parts (except tips of mandibles), a spot on clypeus, a narrow margin between compound eyes and mouth-parts, ventral aspect of thorax, legs (except a dark band on coxæ and femora), membrane at base of abdomen, caudal margin of each abdominal segment ventrally, a more or less well-marked spot on each side of first and second abdominal segments, a broad band occupying caudal threefourths of third and fifth segments, a narrow band on caudal margin of sixth segment often more or less interrupted forming spots on back and sides, and latero-caudal angles of seventh segment, yellow in male.

In female, spots and bands usually smaller and sometimes entirely wanting ventrally.

Both this species and Cephus cinctus vary greatly in their markings. Mr. S. A. Rohwer, of the Bureau of Entomology, who has giren much critical study to this genus and has examined a large series of individuals, mostly reared from known host plants, states in a recent publication: ${ }^{2}$ "The introduced, European, Cephus pygmaeus (Linnaeus) is very similar to the native species common throughout the west and it is difficult to find characters which distinguish the two in all their forms."

1 Comstock, J. H. A saw-fly borer in wheat. In Bul. 11, Agr. Exp. Sta. Cornell Univ., Nov., 1889.

2 Rohwer, S. A. The American species of the genus Cephus Latreille. In Proc. Ent. Soc. Wash., v. 19, p. 139-141. 1917.

ADDITIONAL COPIES

OF THIS PUBLICATION MAY BE PROCURED FROM THE SUPERLNTENDENT OF DOCUMENTS GOVERNMENT PRINTING OFFICE WASHINGTON, D. C. 
